\title{
Intracellular Peptide Hydrolysis by Pseudomonas putida and Pseudomonas maltophilia
}

\author{
By T. CASCIERI, JR* AND M. F. MALLETTE \\ Department of Biochemistry, The Pennsylvania State University, \\ University Park, Pennsylvania I6802, U.S.A.
}

(Received I8 June 1975; revised II August 1975)

\begin{abstract}
SUMMARY
Amino acids liberated by peptidase hydrolysis of di- and oligopeptides by Pseudomonas putida were measured by trinitrobenzenesulphonate assay and high voltage electrophoresis or paper chromatography followed by ninhydrin spray. Intact bacteria or periplasmic contents released by lysozyme treatment did not hydrolyse peptides. Subcellular fractionation showed that glycylmethionine peptidase activity was cytoplasmic. This enzyme had a $K_{m}$ of $2 \mathrm{~mm}$, and was stimulated fivefold by I $\mathrm{mM}^{-\mathrm{Co}^{2+}}$. Crude peptidase extract did not cleave peptides with D-residues, acylated $\mathrm{N}$-terminal amino groups or $N$-methylated peptide bonds but otherwise showed a wide specificity. Di- or tripeptides with blocked C-terminus were hydrolysed. Leucylleucine (I $2 \mathrm{mM}$ ) and leucylglycylglycine (Io $\mathrm{mM}$ ) did not compete with glycylmethionine ( $1.2 \mathrm{~mm}$ ) and glycylmethionylglycine (I.0 $\mathrm{mm})$, respectively, for hydrolysis. Pseudomonas maltophilia also contained peptidase activity $(0.84 \mu \mathrm{mol}$ amino acid released from glycylmethionylglycine $/ \mathrm{min} / \mathrm{mg}$ protein). Peptidases of both $P$. putida and $P$. maltophilia were constitutive.
\end{abstract}

\section{INTRODUCTION}

Utilization of peptides for growth by bacteria is a two-step process, involving both uptake and hydrolysis. Investigation of peptide hydrolysis was necessary to understand the uptake process and was studied simultaneously with work on peptide uptake (Cascieri \& Mallette, 1976).

Peptidases probably do not exist exclusively to hydrolyse peptides transported by microorganisms which can grow in glucose-salts media. Their major function is probably participation in intracellular protein degradation and turnover (Pine, 1972; Goldberg \& Dice, 1794). Accordingly, experiments were designed to locate peptidase activity in Pseudomonas and to delineate any stereo- and structural specificities. These studies were expected to aid in understanding the assimilation of peptides by pseudomonads.

\section{METHODS}

Chemicals. $\alpha$-N-acetylglycylmethionine and $\alpha$-N-acetylglycylmethionylglycine were prepared according to Naider, Becker \& Katzir-Katchalski (1974). Ethyl ester hydrochlorides of peptides were prepared with thionyl chloride in ethanol (Brenner \& Huber, I953). Sources of other peptides and peptide derivatives were as described previously (Cascieri \& Mallette, 1976). 2,4,6-Trinitrobenzenesulphonate (TNBS) and lysozyme were purchased

\footnotetext{
* Present address: FMC Corporation, Industrial Chemical Division, Princeton, New Jersey 08540, U.S.A.
} 
from Nutritional Biochemicals Corp. (Cleveland, Ohio, U.S.A.). All amino acid residues are of the L-configuration unless stated otherwise.

Micro-organisms. The bacterial strains used and the growth and processing of cultures were described in the preceding paper (Cascieri \& Mallette, 1976).

Preparation of peptidase. Pseudomonas putida and $P$. maltophilia were grown to an $E_{650}$ of 0.4 to 0.6 on minimal glucose-salts medium (Cascieri \& Mallette, 1976), centrifuged at Io $000 \mathrm{~g}$ for $10 \mathrm{~min}$ at $4{ }^{\circ} \mathrm{C}$, then washed and centrifuged twice with cold $0.9 \%(\mathrm{w} / \mathrm{v}) \mathrm{NaCl}$ equal in volume to the original culture. The pellet was resuspended in 0.02 M-potassium phosphate $\mathrm{pH} 7 \cdot 4$ and sonicated for five $30 \mathrm{~s}$ periods. This suspension was centrifuged at I0000 $\mathrm{g}$ for $30 \mathrm{~min}$ at $4 \mathrm{C}$. The supernatant liquid was taken as crude peptidase preparation. Such extracts contained 50 to $200 \mu \mathrm{g}$ protein $/ \mathrm{ml}$ as assayed by the Lowry et al. (I95I) method using bovine serum albumin as the standard.

Peptidase assays. To $\mathrm{I} \mathrm{ml}$ of the above extract, $\mathrm{O} \cdot \mathrm{I} \mathrm{ml}$ of appropriate peptide substrate was added, and the system shaken at $30^{\circ} \mathrm{C}\left(37^{\circ} \mathrm{C}\right.$ for $P$. maltophilia $)$ for 15 to $60 \mathrm{~min}$. After incubation, reaction mixtures were frozen (dry ice--isopropanol) and assayed for hydrolysis products within $24 \mathrm{~h}$. Suspensions of intact bacteria were incubated in this procedure to permit assay of extracellular peptidase activity. The bacteria were removed after incubation by centrifuging or filtration with a Millipore filter $(0.45 \mu \mathrm{m}$ pore size). Controls containing peptide only and either enzyme extracts or whole bacteria without peptide were also incubated.

The products of peptidase activity were determined in three ways. (i) The procedure of Binkley, Leibach \& King (I968), as modified by Payne (1972), in which TNBS reacts with free amino groups of amino acids liberated by peptidase action was used. $\mathrm{Cu}^{2+}$ was added to prevent peptide amino groups from reacting extensively with the TNBS. A mixture of $4 \mathrm{ml}$ of $2.5 \%(\mathrm{w} / \mathrm{v})$ sodium borate decahydrate and $0.015 \% \mathrm{CuSO}_{4}$ with $0.5 \mathrm{ml}$ of $4 \mathrm{mg}$ TNBS $/ \mathrm{ml}$ was added to $0 . \mathrm{I}$ to $0.5 \mathrm{ml}$ of the incubation mixture to be assayed for peptidase hydrolysis products. The assay system was warmed at $37{ }^{\circ} \mathrm{C}$ for $20 \mathrm{~min}$, then $\mathrm{O} \cdot \mathrm{I} \mathrm{ml}$ of I I $\mathrm{M}-\mathrm{HCl}$ was added, immediately mixed and the extinction of the sample read at $420 \mathrm{~nm}$. Controls containing peptide only, extract only or standard amino acids were assayed in the same way.

(ii) For peptidase assay by high voltage electrophoresis, $25 \mu 1$ samples of incubation mixtures were applied to Whatman $3 \mathrm{MM}$ paper and run at a gradient of 40 to $50 \mathrm{~V} / \mathrm{cm}$ generated with HV-5000 power supply (Savant Instruments). Buffer was pyridine-acetic acid-water ( $\mathrm{I}: 10: 89$, by vol.) at $\mathrm{pH} 3.5$. The paper was then dried at $40{ }^{\circ} \mathrm{C}$ overnight, and amino acids and peptides were detected with $0.5 \%(\mathrm{w} / \mathrm{v})$ ninhydrin in acetone followed by heating at $100{ }^{\circ} \mathrm{C}$ for $3 \mathrm{~min}$. Compounds without free $\mathrm{N}$-terminal amino groups were detected by exposure to $I_{2}$ vapour. Amino acid and peptide standards were run at the same time. Indigo tetrasulphonate was used as the marker. This assay was used for qualitative and semi-quantitative work.

(iii) Peptidase incubation mixtures $(25 / 1)$ were also assayed chromatographically on Whatman $3 \mathrm{MM}$ paper with upward development in I-butanol-4 $\mathrm{M}-\mathrm{NH}_{4} \mathrm{OH}$-ethanol ( I $1: 8: 4$, by vol.). Samples were applied to areas of equal diameter with intermittent drying. Peptide and amino acid standards in $25 \mu$ were run at the same time. After drying and spraying with ninhydrin, chromatograms were evaluated visually.

Subcellular fractionation. Fractionation was modified from the method of Stinnett, Guymon \& Eagon (1973). Pseudomonas putida was grown in $150 \mathrm{ml}$ of minimal medium to 0.4 turbidity, with shaking at $200 \mathrm{rev} . / \mathrm{min}$ at $30 \mathrm{C}$. Bacteria were centrifuged at $10000 \mathrm{~g}$ for $10 \mathrm{~min}$ at $25^{\circ} \mathrm{C}$ and resuspended in $90 \mathrm{ml}$ of solution containing: $0.75 \mathrm{M}$-sucrose, $2.5 \%$ 
$(\mathrm{w} / \mathrm{v}) \mathrm{LiCl}, \mathrm{O} \cdot \mathrm{OI} \mathrm{M}$-potassium phosphate and 0.0 I $\mathrm{M}-\mathrm{MgSO}_{4}$ at $\mathrm{pH} 7 \cdot 4$. Lysozyme was added at $500 \mu \mathrm{g} / \mathrm{ml}$. The suspension was incubated for $\mathrm{I} h$ at $30{ }^{\circ} \mathrm{C}$ and centrifuged at $10000 \mathrm{~g}$ for $30 \mathrm{~min}$ at $4{ }^{\circ} \mathrm{C}$. The supernatant contained periplasmic materials and portions were assayed for glycylmethionine peptidase activity. One-sixth of the pellet (i.e. the sphaeroplasts) was resuspended in fresh sucrose-salts solution, sonicated as below, and assayed for glycylmethionine peptidase. Peptidase activities in the periplasm and sphaeroplasts could be compared directly since any effects on activity by medium components were kept constant.

The second one-sixth portion of the original spheroplast pellet was dispersed in $12.5 \mathrm{ml}$ of $0.01 \mathrm{M}$-potassium phosphate-0.001 $\mathrm{M}^{-\mathrm{MgSO}_{4}}\left(\mathrm{pH}_{7} \cdot 4\right)$ and sonicated in ice for three $30 \mathrm{~s}$ periods (Sonifier cell disruptor model W $\mathrm{I}_{4} \mathrm{OD}, 0.5$ inch tip). Portions were assayed for glycylmethionine peptidase, glucose-6-phosphate dehydrogenase (as the cytoplasmic marker) (Hylemon \& Phibbs, 1972) and glucose dehydrogenase (as the membrane marker) (Hauge, I 966). These activities represented the sphaeroplastic totals and were used to establish relative values for the cytoplasmic and membrane fractions.

The remaining two-thirds of the original spheroplast pellet, suspended in $\mathrm{I} \mathrm{ml} \mathrm{of} 2.5 \%$ (w/v) $\mathrm{LiCl}-0.75 \mathrm{M}$-sucrose at $4{ }^{\circ} \mathrm{C}$, was added rapidly to $50 \mathrm{ml}$ of cold 0.01 M-potassium phosphate-0.00 I M- $\mathrm{MgSO}_{4}\left(\mathrm{pH}_{7} .4\right)$ and mixed for $10 \mathrm{~s}$ to disrupt the cells osmotically. The mixture was centrifuged at $40000 \mathrm{~g}$ for $30 \mathrm{~min}$ at $4{ }^{\circ} \mathrm{C}$. The supernatant liquid contained cytoplasmic materials and was assayed as before for glycylmethionine peptidase, glucose-6phosphate dehydrogenase and glucose dehydrogenase. The pellet contained membranous residues and was suspended in $50 \mathrm{ml}$ of $0.01 \mathrm{M}$-potassium phosphate-0.00 I $\mathrm{M}-\mathrm{MgSO}_{4}$ $\left(\mathrm{pH}_{7} \cdot 4\right)$ and dispersed with three 30 s sonication periods. This particulate suspension was assayed for glycylmethionine peptidase, glucose-6-phosphate dehydrogenase and glucose dehydrogenase. Activities were reported as relative percentages of sphaeroplast contents.

\section{RESULTS}

\section{Location of peptidase in P. putida}

The presence of extracellular peptidase would permit early hydrolysis followed by uptake of released amino acids. Therefore, the cellular location of peptidase activity was of critical importance to the study (Cascieri \& Mallette, 1976) of peptide uptake. Pseudomonas putida was centrifuged, washed twice with $0.9 \% \mathrm{NaCl}$ and re-centrifuged. Bacteria $\left(6 \times 10^{8}\right.$ cells $/$ $\mathrm{ml}$ ) were incubated in $0.02 \mathrm{M}$-phosphate buffer $\mathrm{pH} 7.4$ with peptide (IO mM), but without a separate energy source, for $30 \mathrm{~min}$. Peptidase activities towards several peptides ( $\mu \mathrm{mol}$ amino acid released $/ \mathrm{min} / \mathrm{mg}$ protein) were as follows: glycylmethionine, o; glycylmethionylglycine, 0 ; glycylglycylgycine, 0.01 . Longer incubation ( 1 to $2 \mathrm{~h}$ ) did not produce further hydrolysis. Incubation conditions in this experiment were chosen to exclude nutrients required for rapid, sustained uptake of hydrolysis products by active transport. Hence, extracellular hydrolysis followed by uptake of released amino acids is not a likely alternative to direct uptake of peptides. On the other hand, sonically-disrupted washed bacteria $(6 \times$ $10^{8} / \mathrm{ml}$ ) from a $30 \mathrm{~min}$ incubation as above hydrolysed peptides (in $\mu \mathrm{mol} / \mathrm{min} / \mathrm{mg}$ protein) as follows: glycylmethionine, 0.36 ; glycylmethionylglycine, 0.21 ; glycylglycylglycine, 0.20 . Accordingly, only intracellular peptidase activity was detected. This same lack of activity by whole cells was reported for Escherichia coli by Simmonds \& Toye (1966). Subsequently, subcellular fractionation of $P$. putida was undertaken to prove that peptidase was intracellular in $P$. putida (Fig. I). Peptidase activity toward glycylmethionine is clearly located in the cytoplasm, as has been observed in other micro-organisms (Wolfinbarger \& Marzluf, 1974; Becker, Naider \& Katchalski, 1973). Approximately $80 \%$ of the glycylmethionyl- 


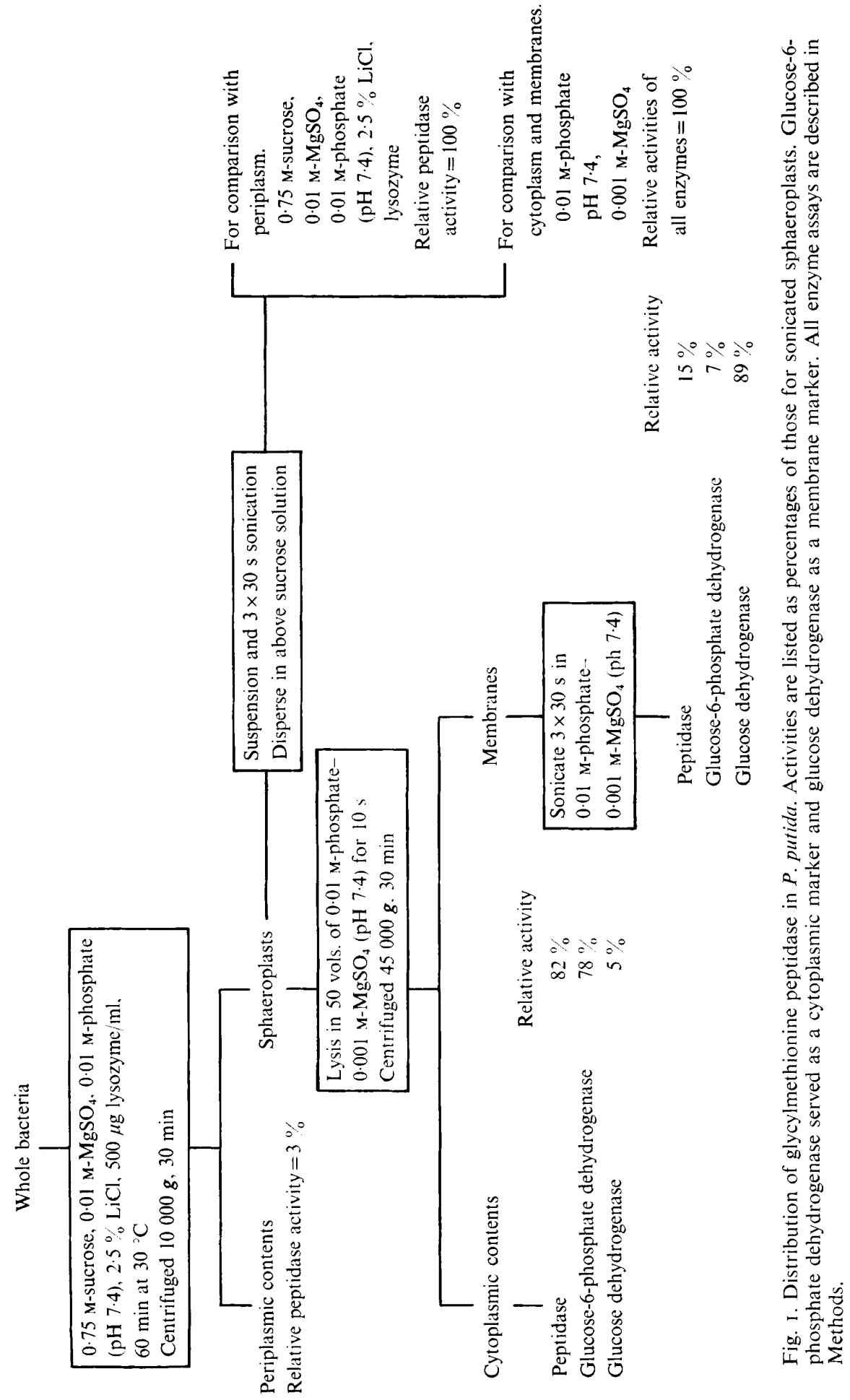


Table I. Peptidase activities of $P$. putida

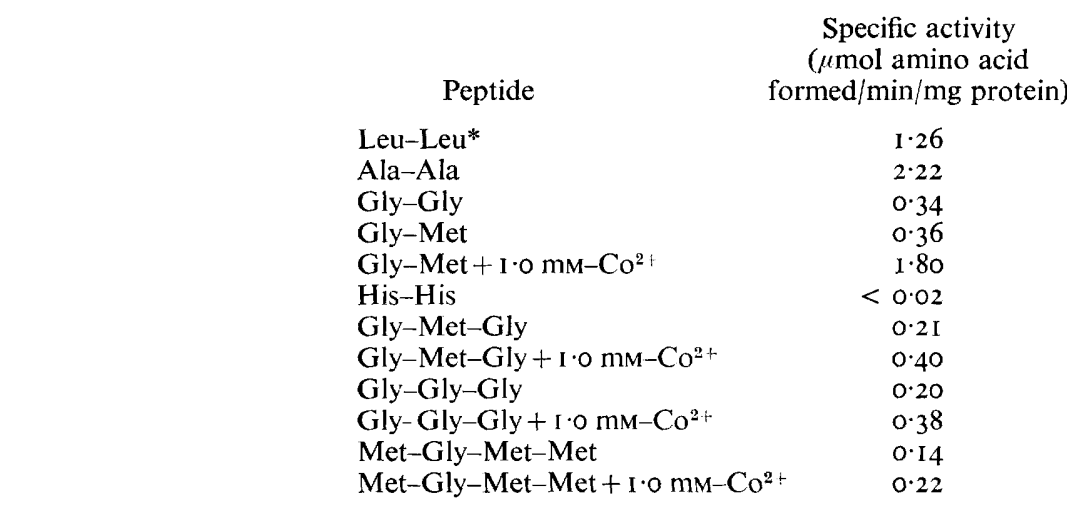

* Initial peptide concentrations differed, but all were between 10 and $12 \mathrm{~mm}$. Incubation times were 15 to $30 \mathrm{~min}$.

glycine peptidase activity was also located in the cytoplasm. The assays on intact bacteria and subcellular fractionation data make a mechanism involving an extracellular peptidase unlikely.

\section{Kinetics of peptidase activity from $P$. patida}

A $K_{m}$ value of $3 \mathrm{~mm}$ and a $V_{\max }$ value of $0.3 \mu \mathrm{mol}$ amino acid released $/ \mathrm{min} / \mathrm{mg}$ protein was obtained from a double reciprocal plot of reaction rate and concentration of glycylmethionylglycine. In another experiment glycylmethionine peptidase had a $K_{m}$ value of $2 \mathrm{~mm}$ and a $V_{\max }$ value of $0.4 \mu \mathrm{mol}$ amino acid released $/ \mathrm{min} / \mathrm{mg}$ protein. Such $K_{m}$ values are comparable to those reported (Payne, 1972) for other bacterial peptidases. These activities are many times in excess of those required to supply $P$. putida met cells growing on methionine peptides with all the methionine necessary for growth. This level of activity combined with efficient uptake by peptide transport, is responsible for the equal effectiveness of peptides or methionine in supporting growth of $P$. putida met. Pseudomonas putida shows varying peptidase activity for a number of different peptide substrates (Table I), as would be necessary if the bacteria are to be capable of utilizing the wide variety of peptides potentially available extracellularly or from intracellular protein degradation. Even histidylhistidine was hydrolysed as shown by chromatographic detection of histidine, although the level of activity was below the limits of the quantitative assay. $\mathrm{Co}^{2+}$ ( $\mathrm{I} \mathrm{mm}$ ) enhanced peptidase activity, as also reported for peptidases of E. coli (Payne, 1972). Pseudomonas maltophilia had a glycylmethionylglycine $(7 \mathrm{~mm})$ peptidase activity of $0.84 \mu \mathrm{mol}$ amino acid released/ $\mathrm{min} / \mathrm{mg}$ protein.

\section{Stereo- and structural specificities of petidase activity}

Structural specificities of these crude peptidase extracts are summarized in Table 2. To ensure maximum hydrolysis, $0.5 \mathrm{mg}$ protein $/ \mathrm{ml}$ and $3 \mathrm{~h}$ incubations were employed. Products were identified qualitatively by comparison with standards following high voltage electrophoresis, thin-layer chromatography and paper chromatography. No unhydrolysed material was found, except with those peptides where no hydrolysis was detected. A D-amino acid, $N$-methylated peptide bond or $N$-acylated terminal amino group prevented peptide hydrolysis under the present conditions. However, C-terminal esterification permitted action of peptidase. Products formed from glycylmethionylglycine and L-leucylglycylglycine 
Table 2. Stereo- and structural specificities of P. putida peptidase*

Peptide (5.0 mM)

D-Leu-L-Leu
L-Leu-D-Leu
L-Leu-L-Leu
Gly-Sarcosine
D-Leu-Gly-Gly
L-Leu-Gly-Gly
Gly-Met-OEt $(\mathrm{I} \cdot 5 \mathrm{~mm})$
Gly-Met
$N$-acetyl-Gly-Met $(\mathrm{I} \cdot \mathrm{O} \mathrm{mm})$
Gly-Met-Gly-OEt
Gly-Met-Gly
$N$-acetyl-Gly-Met-Gly $(\mathrm{I} \cdot \mathrm{O} \mathrm{mm})$
BZC + -Gly-Gly-Met $(\mathrm{I} \cdot \mathrm{Om})$

Products $\dagger$

No hydrolysis

No hydrolysis

Leu

No hydrolysis

No hydrolysis

Leu,Gly,Gly-Gly (trace)

Gly,Met,Met-OEt

Gly, Met

No hydrolysis

Gly,Met,Met-Gly-OEt (trace), Gly-OEt

Gly,Met,Met-Gly (trace)

No hydrolysis

No hydrolysis

* Incubation conditions described in Methods.

$\dagger$ Hydrolysis products were separated by high voltage electrophoresis.

BZC, benzyloxycarbonyl.

Table 3. Peptidase activity on Gly-Met, Leu-Leu and a mixture

Substrate

Gly-Met $(1 \cdot 2 \mathrm{~mm})$
Leu-Leu $(12 \cdot 1 \mathrm{mM})$
Gly-Met $(1 \cdot 2 \mathrm{mM})+$ Leu-Leu $(12 \cdot 1 \mathrm{~mm})$
(experimental)
Gly-Met $(1 \cdot 2 \mathrm{~mm})+$ Leu-Leu $(12 \cdot 1 \mathrm{mM})$
(expected if additive)
Specific activity

$\left(E_{420} / \mathrm{min} / \mathrm{mg} /\right.$ protein $)$

0.37

$1 \cdot 08$

I 43

$1 \cdot 45$

indicate that peptidase action might begin at the $\mathrm{N}$-terminal residue, which would explain the difference between peptidase activity on blocked N-terminal and blocked C-terminal peptides. Purification might reveal enzymes with other stereo- and structural specificities. However, the most active peptidases had the substrate preferences listed above.

\section{Lack of competition between peptides for petidase}

Studies of peptide transport were based in part on competition between peptides during growth experiments. Presumably competition took place during peptide entry, but it could be argued that competition occurred at the level of peptide hydrolysis, not peptide transport. Hydrolysis of glycylmethionine $(1 \cdot 2 \mathrm{~mm})$ by $P$. putida peptidase was not affected by $\mathrm{I} 2 \mathrm{~mm}-$ leucylleucine (Table 3). Because the concentration of glycylmethionine was insufficient to saturate the peptidase, additivity of the two activities does not necessarily mean that two separate enzymes were present; more rigorous kinetic data would be required to substantiate this. Paper chromatography of reaction mixtures showed that equal quantities of glycine and methionine were liberated in the presence or absence of 12 mm-leucylleucine, but the data are only semiquantitative. In contrast, a I: I ratio of leucylleucine to glycylmethionine in the growth medium of $P$. putida met significantly inhibited growth (Cascieri \& Mallette, 1976). Yet even the 10: I ratio of leucylleucine to glycylmethionine (Table 3) had no effect on glycylmethionine hydrolysis. These results confirm the suggestion of Payne (I968) for $E$. coli that competition studies with auxotrophs accurately reflect events at the level of peptide entry, not peptide hydrolysis. 
Possible competition between oligopeptides for peptidase action was also examined. Peptidase was added to glycylmethionylglycine (I mM), leucylglycylglycine (Io $\mathrm{mM}$ ) and a mixture of both. Incubation mixtures were examined as described above. The following peptide combinations were hydrolysed to the indicated products: glycylmethionylglycine (I $\mathrm{mm}$ ) gave glycine and methionine; glycylmethionylglycine (I $\mathrm{mM}$ ) plus leucylglycylglycine (I0 $\mathrm{mM}$ ) gave glycine, methionine, leucine and glycylglycine (trace); leucylglycylglycine (IO mM) gave leucine, glycine and glycylglycine (trace). Since these incubations were at glycylmethionylglycine concentrations below the $K_{m}$, and since the method was semiquantitative, this information only suggests that leucylglycylglycine did not prevent hydrolysis of glycylmethionylglcyine by peptidase although it was a potent inhibitor of growth by $P$. putida met on glycylmethionylglycine (Cascieri \& Mallette, 1976). Nevertheless, the above observations do indicate that competition took place at the level of peptide uptake, not peptide hydrolysis.

\section{DISCUSSION}

The intracellular location of peptidase activity established here for $P$. putida by subcellular fractionation agrees with observations in E. coli (Simmonds \& Toye, I966), and in Saccharomyces cerevisiae and Neurospora crassa (Wolfinbarger \& Marzluf, 1974). This location is not surprising considering the role ascribed (Pine, 1972) to peptidases in intracellular protein turnover. Even those micro-organisms which excrete extracellular proteases such as N. crassa (Wolfinbarger \& Marzluf, 1974) and Seratia marcescens (Payne \& Gilvarg, 1971) have intra-cellular peptidases. Presumably the protease-producing organism $P$. maltophilia is similar in this respect.

Michaelis constants of 2 to $3 \mathrm{~mm}$ for peptidase activity in P. putida are comparable to those of 2 to $6 \mathrm{~mm}$ reported by Payne (1972) for $E$. coli peptidases. Differences like those in activity toward different peptide substrates and $\mathrm{Co}^{2+}$ stimulation of activity for $P$. putida peptidases have been reported for peptidases from other micro-organisms (Payne, 1972; Behal \& Folds, 1967) and from mammalian cells (Binkley et al., 1968).

The assays allowed measurement of peptidase activity towards natural substrates rather than such artificial ones as amino acid $\beta$-naphthylamides. This point is important since Miller \& Mackinnon (1974) found several peptidases in Salmonella typhimurium, only one of which was active against amino acid $\beta$-naphthylamides.

A peptide hydrolysis system is useful in converting transported peptides to amino acids for protein synthesis and in completing the degradation of proteins during turnover. For efficiency, non-functional proteins, whatever their source, are hydrolysed successively to peptides and to amino acids thus allowing amino acids to be recycled.

All peptidase activities were measured in bacteria grown in media without added peptides. Therefore, peptidase activity was constitutive. However, it is possible that peptidase levels could be stimulated by exogenous peptides or increased protein degradation.

This work was partially supported by the Pennsylvania Agricultural Experiment Station.

\section{REFERENCES}

Becker, J. M., Naider, F. \& Katchalski, E. (I973). Peptide utilization in yeast. Studies of methionine and lysine auxotrophs of Saccharomyces cerevisiae. Biochemica et biophysica acta 291, 388-397.

Behal, F. J. \& Folds, J. D. (I967). A comparative study of bacterial alanine aminohydrolases. Biochemical and Biophysical Research Communications 27, 344-349. 
Binkley, F., Leibach, F. \& KING, N. (I968). A new method of peptidase assay and the separation of three leucylglycinases of renal tissues. Archives of Biochemistry and Biophysics 128, 397-405.

Brenner, M. \& Huber, W. (I 953). Herstellung von $\alpha$-Aminosäureestern durch Alkoholyse der Methylester. Helvetica chimica acta 36, I 109-1 I I 5.

Cascieri, T. \& Mallette, M. F. (1976). Peptide utilization by Pseudomonas putida and Pseudomonas maltophilia. Journal of General Microbiology 92, 283-295.

Goldberg, A. L. \& Dice, J. F. (1974). Intracellular protein degradation in mammalian and bacterial cells. Annual Review of Biochemistry 43, 835-869.

Hauge, J. G. ( I 966). Glucose dehydrogenases - particulate. I. Pseudomonas species and Bacterium anitratum. Methods in Enzymology 9, 92-98.

Hylfmon, P. B. \& PhibBs, P. V. (1972). Independent regulation of hexose catabolizing enzymes and glucose transport activity in Pseudomonas aeruginosa. Biochemical and Biophysical Research Communications $\mathbf{4 8 ,}$ $1041-1048$.

Lowry, O. H., Rosebrough, N. J., Farr, A. L. \& Randall, R. J. (195I). Protein measurement with the Folin phenol reagent. Journal of Biological Chemistry 193, 265-275.

Miller, C. G. \& Mackinnon, K. ( 1974). Peptidase mutants of Salmonella typhimurium. Journal of Bacteriology r20, 355-363.

Naider, F., Becker, J. M., \& Katzir-Katchalski, E. ( 1974). Utilization of methionine-containing peptide and their derivatives by a methionine-requiring auxotroph of Saccharomyces cerevisiae. Journal of Biological Chemistry 249, 9-20.

PAYNE, J.W. (1968). Oligopeptide transport in Escherichia coli. Specificity with respect to side chain and distinction from dipeptide transport. Journal of Biological Chemistry 243, 3395-3403.

Payne, J. W. (1972). The characterization of dipeptidases from Escherichia coli. Journal of General Microbiology $7 \mathbf{1}, 267-279$.

Payne, J. W. \& Gilvarg, C. (1971). Peptide transport. Advances in Enzymology 35, 187-244.

PINe, M. J. (1972). Turnover in intracellular proteins. Annual Review' of Microbiology 26, 103-126.

Simmonds, S. \& Toye, N. O. (I 966). Peptidases in spheroplasts of Escherichia coli K-I 2. Journal of Biological Chemistry 24x, 3852-3860.

Stinnett, J. D., Guymon, L. F. \& Eagon, R. G. (1973). A novel technique for the preparation of transportactive membrane vesicles from Pseudomonas aeruginosa: observations on gluconate transport. Biochemical and Biophysical Research Communications 52, 284-290.

Wolfinbarger, L. \& Marzluf, G. A. (1974). Peptide utilization by amino acid auxotrophs of Neurospora crassa. Journal of Bacteriology 1x9. 371-378. 